\title{
Beyond accountants as technocrats: A common good perspective
}

\author{
Sandrine Frémeaux \\ Audencia Business School \\ 8 route de la Joneliere \\ 44312 Nantes, France \\ sfremeaux@audencia.com \\ François-Régis Puyou (corresponding author) \\ The University of St Andrews \\ School of management, The Gateway \\ St Andrews, Fife \\ KY16 9RJ Scotland \\ frp2@st-andrezs.ac.uk \\ Grant Michelson \\ Macquarie University \\ Department of Marketing and Management \\ NSW, 2109, Australia \\ grant.michelson@mq.edu.au
}

\begin{abstract}
:
In a context characterised by the scientification of accounting practices and standards, an important question to pose is how might accounting professionals be released from an excessive focus on rationality (technical accuracy, technical neutrality and technical abstraction) and reclaim the profession in the public interest? Grounded in a person-oriented approach, we contend the common good principle can help accountants to mitigate the tyranny of economic rationality/homo economicus notably through greater consideration of public interest, thereby enabling them to exercise stronger ethical judgement. First, the common good can serve as a basis for the establishment of an ethical protocol based on the search for embedded community goods, human development and the personal good of each member. Second, the common good provides specific ethical principles including subsidiarity, totality, teleological hierarchy, longterm commitment, reality and unity that can better assist accounting professionals to exercise ethical judgement and therefore contribute to the public interest. In contrast to defending a strict adherence to ethical rules enshrined in professional codes of conduct, this article argues for an open ended protocol inspired by the common good principle. This will, we contend, better promote the re-contextualisation of accounting practices conducted by reflexive, sentient and publically-conscious practitioners.
\end{abstract}

Keywords: Common good; Catholic social teaching; Public interest; Scientification. 
'Science sans conscience n'est que ruine de l'âme' 'Science without conscience is nothing but ruin to the soul'

François Rabelais, Pantagruel, 1532

\section{Introduction}

A longstanding critique of the work that accounting professionals do is the often assumed notion that the logical, systematic and rigorous production of numbers and documents is sufficient. There is an orthodoxy that the financial figures that result from this process are somehow unassailable and speak an objective 'truth' and rationality into the state of the particular situation to which they are being applied (Aho, 2005; Gill, 2011). However, as Townley et al. (2003) contends, “Too often numbers are deemed to speak for themselves and preclude debate” (p. 1062). This common orthodoxy precludes the findings of research that shows that the numbers produced by accountants are not neutral and can lead to a range of consequences, both intended and unintended, depending on various sectional interests (Bebbington et al., 2007; Puxty, 1986). Indeed, accounting is both a moral and discursive practice and, importantly, accountants cannot discount or ignore their own moral agency (Francis, 1990). Consequently, a major challenge for the accounting field is to encourage professionals to be involved beyond the mere adherence to national and international accounting standards and ensuring decision relevance, and consider how the agency of their work impacts the greater good - including justice - of communities and societies (see Pallot, 1991). For some commentators (e.g. Lehman, 2010, 2014) this means making better judgements in the public interest as well as interrogating how accounting can actively contribute to the democratisation of civil society.

The endeavour by some scholars to broaden the scope of accounting and the work of accounting professionals to consider the wider good resonates with MacIntyre's (1984) focus on the social and not the individual in explaining morality, and Habermas' ([1981] 1987) concern that a consequence of 'the law', an instrument that is more formal, positive and written, results in citizens being 'unburdened' or relieved of various moral deliberations. The same phenomenon is evident in accounting (Power, 1997; Power \& Laughlin, 1996) and especially with the construction of the principal-client or agent arrangement (Hanlon, 1996). This transactionally-oriented and principal-dependent relationship provides principals with outcomes that can then be potentially used to control others' (Nelson, 1993). Some contend that this is a perversion of accounting that is dialogical in nature (see Neu, 2000). Against this 
backdrop, we inquire whether reference to the common good principle might help mitigate the excesses of economic rationality writ large, and inject more moral consciousness into the work of accountants.

Previous research has examined whether the common good principle could be a foundation for organisations (Schlag, 2012) or management practice (Acevedo, 2012; Melé, 2012; Spitzeck, 2011). Our specific interest is whether common good can serve as a useful guide for accounting professionals. Including a consideration of the public interest while searching for embedded communities, human development and the personal good of each member, the common good perspective might help mitigate excessive objectification and rationality of accounting practices.

Drawing on the work of Habermas, McIntyre and the wider notion of the common good as understood in Catholic social teaching (CST), our purpose in this paper is to show how accounting professionals can transcend the limitations of the assumed rationality, scientification and objectivity of much of their work. In specific terms, how can the accounting profession pursue a community good by developing a higher awareness of societal needs? How can accountants pursue human development and satisfy the public interest through more engaged moral consideration? Our analysis will argue for, and then demonstrate, how a protocol that places the common good at the centre of accounting practices may enable accounting professionals to better support the public interest as part of their professional responsibilities and duties. Our main contribution is to indicate how the philosophical notion of common good provides a theoretical framework as well as practical ethical principles including subsidiarity, totality, teleological hierarchy, long-term commitment, reality and unity that can better guide the exercise of ethical judgement in accounting and foster the re-contextualisation of ethical norms and accounting practices. In short, our far-reaching vision is to help accounting professionals become 'good practitioners' as opposed to merely being 'neutral technocrats' (see Bebbington et al., 2007, p. 368).

More broadly speaking, we argue that our position is consistent with the evolution being experienced in the accounting profession towards becoming 'business partners' (e.g. Jarvenpaa, 2007). It is also consistent with some who have called for accounting professionals to become 'critically reflexive practitioners' (Gallhofer et al., 2015, p. 865) with concern for the moral and political consequences of their actions. In doing so, this paper contributes to the body of work aimed at restoring the role and trust of accounting professionals in deliberations around accounting and financial information (in support of the public interest). The remainder of the article is structured as follows. We discuss in the following section the phenomenon and 
ascendancy of new institutionalism and the manifest rationality of accounting practices through textualisation and scientification. In the third section, we present the theory on the common good principle, its provenance, meaning and relevance, while the fourth section examines how the common good principle can foster the increased moralisation and public interest role of accounting practices. In section five, we discuss the implications of our argument before the final section concludes by showing our contribution to the critical accounting literature.

\section{The objectification and rationality of accounting practices}

Historically, accounting has proved helpful to assess the legitimacy of its relations with other institutions and stakeholders (Aho, 2005; Richardson, 1987; Richardson \& Eberlein, 2011). Claims from business partners, clients, suppliers and creditors are, for example, recorded as liabilities that will need to be settled equitably. Accounting's concern for balanced relationships is made explicit in the methodological guidelines for constructing the balance sheet in order to generate the idea that, in the case of the business in question, "we owe no more than what we have received and we have no more than what we have already given” (Aho, 1985, p. 33). Consequently, accounting professionals are primarily concerned with what elements are incorporated or omitted to achieve a fair balance (Ravenscroft \& Denison, 2014). In large part, this tendency towards legitimacy, standardisation and rationality in the field of accounting has been influenced by work on new or neo-institutionalism in organisation studies (e.g. Meyer, 1986; Meyer \& Jepperson, 2000; Meyer \& Rowan, 1977). Neo-institutionalism (and variants of it) posits that institutions like accounting develop similarities and shared 'logics of appropriateness' that guides the behaviour of human actors within them. Individual actors can benefit (for instance, status, recognition) when they conform to the institutional rules and standards since this is a way to maximise their own utilities.

However, the outcomes of institutionalised adherence to economic rationality/ homo economicus can be exposed and the accounting profession has been sharply criticised in the context of recent and yet spectacular frauds and bankruptcies (e.g. Rogers et al., 2005). Slavish conformity to accounting standards and ensuring decision relevance has arguably led to a collapse in confidence towards accounting professionals. How can accountants continue to be promoters of fairness and transparency and yet, according to social accounting theorists (Ball \& Osborne, 2011; Deegan, 2017), still connect accounting with the public interest through its social, economic and environmental responsibilities? The ability of accountants to ensure sound 
and ethical business practice depends on their professional legitimacy obtained through technical competence, and on their respect of codified moral and ethical guidelines.

We contend that neo-institutionalism has militated against the development of the public interest role of accounting professionals as a result of two interlinked phenomena: the 'textualisation' of ethical guidelines and the 'scientification' of accounting practices. The gradual textualisation of ethical guidelines is characterised by a surge in the production of ethical codes, dedicated exams on ethics, and the multiplication of standards and guidelines on moral and ethical behaviours (Velayutham, 2003). For its part, the growing scientification of accounting practices has resulted, inter alia, from professional bodies' attempts to turn accounting from a craft and an occupation to a profession grounded on scientific knowledge (Lee, 1995). These processes of modernisation rationalise all institutions, increasing the prospect that citizens are increasingly disenfranchised and less able to democratically participate in the public sphere (Habermas, 1981 [1987]). It is argued that both evolutions have undermined the conditions for personal subjective moral judgement, and for taking into account the wider social community in their daily work as professional accountants. This perspective will now be further developed.

\subsection{The 'textualisation' of accounting ethical guidelines}

In several western countries the accounting profession started to organise itself at the end of the 19th century following existing prestigious professions including lawyers (for example, in Ireland and in the UK) or engineers (for example, in the US) (McMillan, 2010). From the outset the intangible qualities of honesty and integrity have been considered essential elements of the ethos of the accounting profession (Chandler, 2016). An important objective of the creation of accounting professional bodies was to gain status and respectability and the formulation of a disciplinary code served the purpose to make intangible moral virtues visible (O’Regan, 2008; Richardson \& Eberlein, 2011). The earliest codes of conduct date from the late 19th century and consisted mostly of a compilation of formerly unwritten rules concocted on an ad hoc basis and enforced by an informal system of peer pressure (Chandler, 2016). The need for ethical standards to become formalised grew with the increase in membership numbers and it is, for example, only following the merger between two professional bodies into the American Association of Public Accountants (AAPA) that the first accounting code of ethics in the U.S. 
was published in $1905^{1}$ (Preston et al., 1995). Codes of ethics ever since have been treated by the accounting profession as an essential tool for supporting its reputation (see Cochran, 1974). Sikka and Willmott (1995) are sceptics about the capacity of formal ethical guidelines to achieve any substantial change in conduct but they show how the refinement of disciplinary arrangements are tactics to neutralise threats to self-regulation by the profession. The codes were indeed used to legitimise the accounting profession within the social realm and it is therefore little surprise they have undergone a number of changes over time (Preston et al., 1995).

The rapidly expanding codes of ethics of the accounting profession have reflected the values of their time marked by a shift from a focus on moral responsibility for a public good to that of technical specification for delivering services in line with formal accounting standards (Velayutham, 2003). The codes have gradually evolved during the 20th century towards greater theorisation and formalisation of practical knowledge and moral obligations. Typically, theories of contemporary U.S. culture tend to emphasise the growing demand for calculative scientific and economic rationality and this concern for adherence to technical standards has impacted accounting (Preston et al., 1995). The 1970s and 1980s saw, for instance, a rise in regulatory structures of accounting practices examining possibilities of greater standardisation of financial reporting (Cooper \& Robson, 2006). This expansion also extended to the public sector and the various accountabilities of governments (Broadbent \& Laughlin, 2003).

The formalisation of moral guidelines into texts (what we refer to as a process of 'textualisation') is not without consequences. Written text, by abstracting words from the flow of speech and from immediate reality through a process of decontextualisation, makes 'talk' objective, abstract and depersonalised (Goody, 1977; Puxty, 1986). Ethical codes are thus a step forward in terms of objectification of ethics and work methods with some direct benefits in terms of the institutionalisation of a profession. Indeed, abstract and decontextualised knowledge are supportive of the development of a robust and distinctive accounting profession (Abbott, 1988). However, objectification also induces additional formalisation causing greater risk of uniformity and a loss of autonomy and openness. There is an ethical danger in relying on abstract principles to guide moral behaviours (Puyou \& Fay, 2015). Unlike context that requires an individual's direct involvement and judgement to be understood, abiding by textual guidelines is a cognitive activity. The more texts accounting professionals have to help them define 'right' behaviours, the less attention they pay to the context and specific circumstances

\footnotetext{
${ }^{1}$ It is remarkable that this code originally contained only two rules, respectively, prohibiting non-members from practicing in members' names, and the payment of referral fees (Preston et al., 1995).
} 
(Young \& Williams, 2010). As a result of textualisation, the ethical acceptability of accounting is assessed by comparing its condition of production with other texts, not by taking into account its effects or consequences. Whatever is allowed by the existing corpus of texts is lawful, and by extension, acceptable.

The codification and formalisation of ethical principles into explicit rules creates a discourse on ethics, an orthodoxy from which deviant practices can then be identified and sanctioned. However, because the accounting profession's codes of ethics are often less concerned with moral responsibility for a public good and interest than with expressing technical specifications supportive of “quality assurance” (Velayutham, 2003), these codes are not ethical discourses in themselves. Once formalised into codes, ethics becomes law-like rules to be applied by account producers and not protocols or stories building on the reality of their subjective lived experience to uncover and adapt their actions to societal needs. Depersonalisation and disembodiment of ethics is therefore a consequence of its formalisation into texts. While administrative rationality is satisfied, wider questions pertaining to serving public interest are not.

\subsection{The 'scientification' of accounting practices}

As argued in the previous sub-section, the 20th century has seen a fundamental shift within the wider public domain with technique and conformity gradually replacing character as an important virtue (Miller \& O’Leary, 1987; Velayutham, 2003). The use of calculative rationality as a legitimating voice has grown over the years putting an emphasis on concepts such as technique, science and technology (Abbott, 1988). In keeping with predictions of neoinstitutionalism, the accounting profession has seen adherence to common standards and an increasingly technical and scientific orientation as a necessary transformation (Preston et al., 1995, p. 530). This shift in the basis for professional legitimacy is broadly reflected in the education provided to future accounting professionals. Professional societies were conceived, right from their creation, as examining bodies supporting the production of competent specialists with certified knowledge (Hoskin \& Macve, 1986). This knowledge has rapidly focused more on technical competence rather than on personal moral values. For example, in the U.S. an explicit ambition of examinations was to distinguish competent professionals from mere amateurs by associating accounting with ‘hard’ sciences (McMillan, 2010).

Increased objectification of accounting knowledge via rigorous assessment of technical mastery has gradually likened accounting to a set of ostensibly neutral techniques. Growing emphasis on formal examinations and extensive training programs has turned accounting from 
a craft to an applied science; a technique that does not suffer uncertainties and that systematically leads practitioners to valuable truths (such as the level of profits, for example). The accounting professional bodies’ appeal to a technical rationality gradually marginalised any discourses placing the public interest above profit (Preston et al., 1995). This shift has therefore given rise to moral implications since accounting information is not primarily seen as satisfying a public need for information anymore, but as a commercial product or service (Abbott, 1988; Hanlon, 1996). In this conception, abiding by standard procedures suffices to make accounting a moral practice; exactness is good and morality lies in objectivity depicted by the absence of personal involvement. As noted by Grafton and Jardine (1986) the shift towards exactness reveals a process of identification of why actions were performed (the end, i.e. a moral issue) with how they are done (the means, i.e. a matter of skill) (see Quattrone, 2015). This new rationale for action made the possession and mastering of appropriate skills as equivalent to virtue: rigorous application of accounting techniques is considered enough to deliver valuable services to the community. The ascendance of Positive Economic Science as the monolithic paradigm of accounting scholarship has largely deprived us of any coherent ethical discourses with which to make sound judgements about the "propriety" of professional behaviour (Williams, 2004).

Accounting has not merely followed a trend imposed on it by wider society but it has also contributed to its own isomorphic evolution towards rationality. For example, auditing has become a significant social phenomenon increasingly involved in the standardisation and formalisation of many areas of community life (Power, 1997). Similarly, accounting education, and especially textbooks, has contributed to the scientification of society spreading such concepts as rationalisation and standardisation (Ferguson et al., 2009). In addition, professional firms such as 'the Big 4' also have proved important sites where accounting practices have been standardised, regulated and reproduced in support of an unwavering belief in the objectivity and value of quantification (Cooper \& Robson, 2006). By becoming a scientific activity, we contend that accounting has given prominence to technical accuracy, objectivity (i.e. the neutral gaze of the scientific observer), and abstraction to the detriment of serious moral and ethical engagement. Rather than assuming a participatory citizenship model in society, under the neoinstitutional perspective reflected in these developments human actors have predominantly become economic citizens (Miller \& O’Leary, 1994). The above arguments are depicted in Table 1 below. 
Table 1: Summary on the textualisation and scientification of accounting practices

\begin{tabular}{|l|l|}
\hline \multicolumn{2}{|c|}{ The objectification and rationality of accounting practices } \\
\hline $\begin{array}{c}\text { Textualisation of ethical guidelines } \\
\begin{array}{c}\text { Cochran (1974); Cooper \& Robson (2006); Goody } \\
\text { (1977); Preston et al. (1995); Puyou \& Fay (2015); } \\
\text { Velayutham (2003); Young \& Williams (2010) }\end{array}\end{array}$ & $\begin{array}{c}\text { Risks inherent to the scientification of } \\
\text { accounting practices } \\
\text { Abbott (1988); Ferguson et al. (2009); Hoskin \& } \\
\text { Macve (1986); McMillan (2010); Power (1997); } \\
\text { Preston et al. (1995); Velayutham (2003); Williams } \\
\text { (2004) }\end{array}$ \\
\hline $\begin{array}{l}\text { Codes mirror social values but ignore societal } \\
\text { needs. }\end{array}$ & $\begin{array}{l}\text { Accounting practices focused on technical } \\
\text { accuracy. }\end{array}$ \\
\hline $\begin{array}{l}\text { Codes formalise morality but are not moral } \\
\text { statements. }\end{array}$ & $\begin{array}{l}\text { Accounting practices focused on technical } \\
\text { neutrality. }\end{array}$ \\
\hline $\begin{array}{l}\text { Codes reinforce abstraction and are } \\
\text { disconnected from reality. }\end{array}$ & $\begin{array}{l}\text { Accounting practices focused on technical } \\
\text { abstraction. }\end{array}$ \\
\hline
\end{tabular}

\subsection{Tensions between moral and ethical calls in contemporary accounting practices}

Despite an unambiguous shift towards the textualisation and scientification of accounting guidelines, most formal codes of ethics still comprise both ethical and quality standards elements (Velayutham, 2003). The idea that contemporary societies are now solely concerned with techniques and ignorant of moral consideration is over simplistic and downplays notable exceptions. For example, O’Regan and Killian (2014) show how, in the context of the Irish auditing industry, accounting bodies have lost power and legitimacy as they failed to recognise the precedence of public interest over expertise in the self-regulatory debate following the 2008 global financial crisis. Drawing on Beck’s (1992) work, these authors show the consequence of accounting experts only too concerned with the definition of risks which are produced by their activities and losing sight of the interests of society. The legitimacy of the professional character has therefore not been completely eclipsed by that of technique. The coexistence of different forms of legitimation contains practical implications for accounting professionals having to decide on occasions between conflicting technical and ethical considerations in their activities. Remarkably, very few accounting professionals, if any, refer to notions of common good or public interest to describe how they cope with such situations (Carcello, 2009; Cooper \& Robson, 2006). The objective of trying to re-orient and recast the accounting profession away from a predictable set of rationally-inspired standards and practices and move towards embracing greater consideration of the public interest remains a challenge. 
Organisational norms and values are often associated with the values of commercialism, bureaucracy and financial gain whereas professional identities are traditionally aligned with the values of integrity and service. Individual accountants are thus commonly forced to reconcile contradictory sets of norms, thereby creating personal dilemmas and dissonance (Maas \& Matejka, 2009). Horton and de Araujo Wanderley (2018) reveal, for example, that within the context of management accounting a longstanding contradiction has existed between the bureaucratic norms inherent in many organisations and the professional principles and ideals that guide many individuals. An accountant's conceptualisation of their professional role identity may thus conflict with an organisation's vision of what this role entails (Goretzki et al., 2013). Faure and Rouleau (2011) also demonstrate that the accounting profession increasingly encounters contradictory pressures when it produces a paradoxical discourse that consists in publicly calling for “'honest, true and fair accounts"' and yet privately deals strategically with them. For instance, management accountants commonly have to make a trade-off between local and corporate loyalties (Hartmann \& Maas, 2010). Slack and earning management practices occurring at the business-unit level are thus often covered by accounting professionals, sometimes on moral grounds such as when it is seen as a legitimate protection for operational staff otherwise subjected to unreasonable expectations from shareholders (Lambert \& Sponem, 2005; Macintosh, 1995). This argument also pertains to the ethical tensions inherent within socalled "creative accounting" when preparers of financial statements manipulate the view they give of economic reality to accommodate the interests of some parties and not others (Gowthorpe \& Amat, 2005). When confronted by various ethical dilemmas, how might accountants begin to rely more on widely shared moral principles and teleological aims to guide their behaviour and not simply revert to the dominant homo economicus imperative? The following section seeks to address this issue.

\section{The common good principle: provenance, meaning and relevance}

The idea of the common good is a central idea in political theory and activism given its potential for contemplating the relationship between individual human actors and the community (Diggs, 1973; Smith, 1999). It is 'common' because "it is facilitated and promoted by the community, and shared by individual members of that community" (Arjoon et al., 2018, p. 153). Unlike the previous section that highlighted the rationalising and self-maximising tendencies of homo economicus as it applies to accounting professionals, the common good does not treat the 
human actor as an isolated individual but in relation to others. For philosophers such as MacIntyre (1984), morals and virtues can only be comprehended in a similar way, or through their relation to the community in which they are derived. Social theorist, Jürgen Habermas, was also interested in various themes relevant to this paper including emancipation, democracy and the public interest. For instance, he is optimistic about the possibility of revival in the public sphere and locates rationality in the structures of interpersonal communication as opposed to in the structure of institutions (McCarthy, 1994; Rasmussen, 1990). This elevates the potential of human agency since rationality, according to Habermas, is achieved through ensuring "all voices in any way relevant can get a hearing” (Habermas, [1981] 1987). In the case of accounting, his theory of communicative action would contend that no proper communication can take place without a set of shared understandings (or, in our interpretation, common good). This stands in contrast to accounting professionals who might let their clients/agents decide about the interpretations of financial accounts. The communicative process envisioned by Habermas can be suppressed or attenuated by major societal institutions; however, it is not deterministic. His perspective nonetheless remains hopeful that making explicit the assumptions and beliefs underlying communicative acts - including those of accountants - can begin to improve the deliberative democracy-reliant process that enhances citizenship and moves away from the dominant rationality of the organisation or nation state. In more recent work, Habermas (2008) and Habermas and Ratzinger (2006) also recognises the positive role of a religious life-world in contributing to the emancipatory and public interest agenda. We continue to develop the concept of the common good along these lines.

\subsection{Humanistic provenance and 'deep' meaning of the common good principle}

With its origins in Judaism and Hellenistic philosophy, the concept of the common good has been used in a diverse range of philosophical, political and economic traditions from Aristotle's philosophy to various subfields including health economics and political science (e.g. Diggs, 1973; Simm, 2011; Smith, 1999). Some ethics scholars have defined common good as "that order of society in which every member enjoys the possibility of realizing his true self by participating in the effects of the cooperation of all” (Messner, 1965, p. 124). Similarly, Finnis (1986, p. 165) regards the common good as "such an ensemble of conditions which enhance the opportunity of flourishing for all members of a community”. Inspired by Aristotelian ethics, the idea of common good has also become a central concept in the modern tradition of Catholic social teaching (CST) and can be defined as "the sum total of social conditions which allow 
people, either as groups or as individuals, to reach their fulfilment more fully and more easily” (Pontifical Commission of Justice and Peace 2004, para 164). In addition to defining the common good, those in the Aristotelian-Thomistic (A-T) tradition also distil its implications for understanding practical action by rational agents (Maritain, 1947). Some Aristotelianinspired scholars, like MacIntyre, eschew any notion that the conception of the autonomous and self-maximising human actor can achieve the common good in the contemporary organisation (MacIntyre, 1984).

Moreover, adherents to Catholic social thought refer to common good as what is shared by all members of a given community rather than what is achieved by collective action (Arjoon et al., 2018). The common good principle, therefore, differs from the political theory of Machiavelli ([1531] 1996) who adopts a procedural ethical view of the common good that is essentially drawn from a free way of life. It is also distinguished from utilitarian economic theories whereby common good tends to be reduced to just the sum of individual goods. Because of its potential to construct a framework that might more deeply elevate the public interest capacity and contribution of accounting professionals (see Ball \& Osborne, 2011; Broadbent \& Laughlin, 2003), we draw on the common good principle based on the Aristotelian-Thomistic (A-T) tradition.

The common good principle is rooted in a personalist approach supported by Mounier (1970) and Maritain (1947) whereby human beings can find fulfilment not in the development of a "having for themselves", but in the pursuit of a community good. This means that individuals can act ethically and flourish at work only when they are decentralised from themselves and turned toward the expanded community good which itself contributes to human development (Sison \& Fontrodona, 2012). Human development implies a set of economic, social, moral and environmental orientations: an economic orientation that allows everyone to enjoy a reasonable level of wellbeing; a social orientation conducive to respect for human freedom, justice and solidarity; a moral orientation shared in a community, including respect for human dignity and human rights; and an environmental orientation that aims to maintain appropriate living conditions for current and future generations (see Melé, 2009). In other words, by pursuing a community good that is turned toward human development, individuals as social beings in that community can seek their personal good, which can only be achieved this way (Melé, 2012; O’Brien, 2009).

Therefore, the common good principle avoids both a focus on individual interests (individualism) and a domination of community based principles (totalitarianism) by proposing a clear connection between community good, human development and personal good. 
Specifically: (i) individuals can act ethically when they are turned toward the community good; (ii) individuals can be turned toward a community good if this good is directed toward human development; and (iii) human development implies that the material realities and situation of each member has to be taken into account. It follows that by participating in a wider community good that contributes to human development without neglecting the personal good of each member, human agents/actors can succeed in exercising sounder ethical judgement than would otherwise be the case.

\subsection{Relevance of the common good principle in accounting}

Sison and Fontrodona (2012) have expressed the aspiration that "an operational managerial paradigm has to be designed based on the new anthropological, political, economic and ethical premises that the common good supplies” (p. 241). Yet, the question is whether the common good principle is sufficiently precise and structured to constitute a clear guide for action (De Bettignies \& Lepineux, 2009; Deissenberg \& Alvarez, 2002). Recent literature deals with this question in a positive manner by focusing specifically on the common good of the firm. Sison and Fontrodona (2012, 2013) used this notion to evoke the particular relationship between community good, human development and personal good, and to emphasise the central importance of collaborative work (Sison \& Fontrodona, 2013, p. 614).

The common good principle could be extremely useful in accounting if used to confront the scientification phenomenon and to prevent accounting professionals from obsessive focus on technical correctness, technical neutrality and technical abstraction when discharging or exercising ethical judgement (see earlier). Lehman (2014) has already proposed to consider accountants as acting like the phronemos, which is Aristotle's term for a wise and ethical person who has the capacity to judge and act appropriately. Along with Everett and Tremblay (2014), Lehman (2014) used virtue ethics to approach the good by considering both the potential virtues of the person of the accountant and the public interest role of accounting practices (see also Lail et al., 2017).

Hence, the common good principle would be pertinent in accounting because it entails the ideal of the public interest, allowing accounting professionals and bodies to overcome both potential and real conflicts of interest. It encourages accounting professionals to resist potential pressure from the client to practice tax avoidance (Addison \& Mueller, 2015), to hide specific financial information, and to resist the potential temptation to increase the quantity of services in order to maximise billing. More generally, the common good principle views accounting not 
merely as a technology to support business decisions and management of economic resources, but also a means of mediating "relations of responsibility” among various parties (Williams, 2014, p. 171), overcoming social conflicts (Baker, 2014), or focusing on the "collective interest of the community as a whole” (Boyce, 2014, p. 126). It has the advantage of transcending the individual and group interests and avoiding the potential abuses committed by accountants or clients (Everett \& Tremblay, 2014; Lehman, 2014).

In other words, the search for the common good in accounting begins with an awareness of the public interest. The term "public" encompasses all individuals and groups: consumers, suppliers and taxpayers, and the concept of public interest requires that costs and benefits be taken into account for society as a whole, while promoting adherence to democratic principles and processes. The analysis of societal consequences implies seeking the validity of financial information and its comparability on a global scale, prudence in public spending, and the contribution of accountants to sound corporate governance and efficiency. Respect for democratic principles means acknowledging established procedures, the independence of professionals and of regulatory, standardisation or public oversight bodies, fair and balanced representation of stakeholders, and the obligation to inform the public.

The concept of common good is not only relevant because it includes a pursuit of public interest; it is also essentially sophisticated, subtle and ambitious (Dellaportas \& Davenport, 2008; Melé, 2009, p. 235), providing a specific protocol based on the consideration of community good, human development and personal good. As such, it is a framework for action and gives accounting professionals the opportunity to bridge different levels of analysis, to combine different disciplines, and to link theory and practice.

\section{Common good principle: a way of moralising accounting practices}

An important challenge is how the search for community good, human development and personal good can enable accountants to better cope with the tensions due, on the one hand, to the growing objectification of their practices through scientification and textualisation and, on the other hand, the ever present contextual factors, moral considerations and personal dilemmas they are confronted with. How does the pursuit of common good enable accounting professionals to avoid an excessive focus on technical accuracy, technical neutrality and technical abstraction? This question generates three additional questions and these encompass the most important aspects of a common good perspective in the pursuit of the public interest. 
Accountants should be asking themselves (1) Which higher community good am I pursuing through my work as an accounting professional?, (2) Which economic, social, moral and environmental orientations am I contributing to?, and (3) How do my work assignments contribute to the personal good of other members of the community? These three questions collectively address the specific principles that underlie the search for common good (see Argandona, 1998; Costa \& Ramus, 2012; Martin, 2011; Melé, 2009, 2012; O’Brien, 2009; Schlag, 2012; Sison \& Fontrondona, 2011, 2012, 2013; Sison et al., 2016). The pursuit of a higher community good occurs as the result of the principles of subsidiarity and totality, and allows accounting professionals to go beyond a mere search for technical accuracy. The pursuit of human development is made possible by the principles of teleological hierarchy and longterm commitment, and encourages accountants not to merely concentrate on technical neutrality. The pursuit of the personal good of each member of a community requires the application of the principles of unity and reality, and helps accountants avoid the pitfalls of technical abstraction.

\subsection{The principles of subsidiarity and totality: challenging the myth of technical accuracy} Just as subsidiarity means, at the political level, that the State encourages firms as private initiatives to better respond to the needs of the wider society (Sison \& Fontrodona, 2012), subsidiarity means, within firms, that employees with a higher level of responsibility provide means and autonomy to those at lower levels to enable them to achieve their objectives and to assume their responsibilities (Melé, 2005). But the subsidiary exercise of authority cannot be limited to the granting of greater autonomy; it also presupposes a clear orientation, one where the community good of the firm fits into a wider community which is the society, enabling both accountants and clients to pursue common objectives and share a common project (Costa \& Ramus, 2012; Sison \& Fontrodona, 2011).

The subsidiarity principle may be reinforced by the application of the totality principle, which encourages leaders, managers and more specifically accounting professionals "to broaden [their] horizons and see the greater good” which will benefit them (Francis, 2013, para 235). This superiority of the whole to the parts also means that "the common good of any community is embedded in the common good of a larger community [so that] the common good of a business firm should be consistent with the common good of society” (Melé, 2009, p. 235). In other words, as Costa and Ramus (2012) have noted, the question of how the common good 
of the firm is embedded in the common good of society can become a fundamental compass for defining the strategic goals of the firm.

The subsidiarity and totality principles invite accounting professionals to regard technical precision as a means at the service of the societal objective of the accounting firm, and not as an end in itself. Encouraged to reflect on how they can respond to societal needs, they can avoid an excessive focus on the technical accuracy imperative.

4.2. The principles of teleological hierarchy and of long-term commitment: challenging the myth of technical neutrality

Economic, legal and ethical disciplines are linked to each other by a teleological hierarchy; that the lower level is at the service of the higher. The first level - material and economic - is foundational (Abela, 2001; Alford \& Naughton, 2002, pp. 42-51; Cortright \& Naughton, 2002). The second level - legal and political - helps to structure and guide the organisation. The third level - ethical, cultural, social, environmental and spiritual - helps to ensure that all the levels are committed to human development.

One common mistake is to focus on the ethical orientation and to lose sight of the economic necessity without which no superior ends of "excellence” will be supported. In accordance with the dialectic of ends and means, profit and capital are explicitly posed as key means for the development of the human person. In this perspective, Sison and Fontrodona (2011) characterise profit as the material part of the common good of business. A second common mistake is to make the first level a condition of the higher levels. As Sison and Fontrodona (2012) have argued, "it would be wrong to pay attention to governance (second level) only when certain profit objectives (first level) have been surpassed, or to consider the cultural development of workers (third level) only when there are no labour conflicts (second level)” (p. 235). Whatever the difficulties or the constraints encountered, the transcendent purpose of a community remains the cultural, moral and spiritual development of each member. Since a focus on maximisation of profit leads to giving too much attention to the "how" instead of the "why” (Benedict XVI, 2009, p. 70), “economic activity needs to be directed towards the pursuit of the common good” (Benedict XVI, 2009, p. 36). Therefore, debates and concerns about the role of accountants in the economic performance of firms, while necessary, do not supplant the central question of how accounting professionals can also contribute to human development and the wider public interest. Accounting professionals can also give priority to long-term commitments (Sison \& Fontrodona, 2011), which invites them "to work slowly but surely, without being obsessed with immediate results” (Francis, 2013, p. 223). By recognising 
that "openness to the transcendent can bring about a new political and economic mindset which would help to break down the wall of separation between the economy and the common good of society" (Francis, 2013, p. 205), accounting professionals could accept that the quest for technical neutrality does not discharge them from a moral account of their actions, and in particular from a contribution to the ethical, cultural and spiritual development of humans and from a commitment to long-term objectives.

\subsection{The principles of reality and unity: challenging the myth of technical abstraction}

The reality principle specifies that realities are more important than ideas, and denounces the numerous denials of reality such as: "angelic forms of purity, dictatorships of relativism, empty rhetoric, objectives more ideal than real, brands of ahistorical fundamentalism, ethical systems bereft of kindness, intellectual discourse bereft of wisdom” (Francis, 2013, p. 231). The risk or danger lies in focusing on profit or image on behalf of a community necessity by concealing the real situation from citizens. Accountants can avoid this denial of reality through a deep and meaningful consideration of the complex reality of their work, enabling each accounting professional to act wisely, and not merely “correctly”, both with and for colleagues and clients.

The reality of work covers the two Aristotelian dimensions of possible activities carried out by human beings: making (poiesis) and doing (praxis). "Making” refers to the external object itself, and to the techniques that are applied in the process of production. "Doing" is an immanent activity that produces changes in the person who is performing the work. According to Sison and Fontrodona (2011), while “making” constitutes an objective dimension guided by technical skills, “doing” constitutes a subjective dimension of work provided by practical wisdom. These scholars consider the reality of work to be a factor of production (making), but also a means for self-perfection (doing). To these two dimensions - objective and subjective Cornwall and Naughton (2003) add a social dimension, which is the community of work. The principle of reality, therefore, encourages accounting professionals to be attentive to the objective dimension of work (tasks), the subjective dimension of work (self-development) and the social dimension of work (the feeling of being a member of a work group).

The unity principle also states that conflicts have to be overcome: “Conflict cannot be ignored or concealed. It has to be faced” (Francis, 2013, p. 226). For accounting professionals, it means that confronting work-related moral dilemmas should be preferred to denying problems or focusing on abstract technical issues in order to escape from being challenged. The arguments in this section are summarised in Table 2 below. 
Table 2: Practical implications of the common good principle in response to the textualisation and scientification of accounting practices

\begin{tabular}{|c|c|c|c|c|}
\hline \multirow{2}{*}{$\begin{array}{l}\text { Risks inherent to } \\
\text { textualisation and } \\
\text { scientification of } \\
\text { accounting } \\
\text { practices }\end{array}$} & \multirow[t]{2}{*}{$\begin{array}{l}\text { Ethical needs of } \\
\text { the accounting } \\
\text { profession }\end{array}$} & \multicolumn{3}{|c|}{$\begin{array}{l}\text { Common good principle } \\
\text { Argandona, 1998; Arjoon et al., 2018; Costa \& Ramus, 2012; Martin, 2011; Melé, 2009, 2012; } \\
\text { O’Brien, 2009; Schlag, 2012; Sison \& Fontrondona, 2011, 2012, } 2013\end{array}$} \\
\hline & & Ethical questions & $\begin{array}{l}\text { Specific ethical } \\
\text { principles }\end{array}$ & Practical implications \\
\hline \multirow[t]{2}{*}{$\begin{array}{l}\text { An excessive } \\
\text { focus on technical } \\
\text { accuracy }\end{array}$} & \multirow[t]{2}{*}{$\begin{array}{l}\text { A higher } \\
\text { awareness of } \\
\text { societal needs }\end{array}$} & \multirow{2}{*}{$\begin{array}{l}\text { Which community } \\
\text { good do I pursue? }\end{array}$} & Subsidiarity principle & $\begin{array}{l}\text { Choice of embedded community reference points } \\
\text { The community good of the accountant's firm is } \\
\text { embedded in the community good of the society. }\end{array}$ \\
\hline & & & Totality principle & $\begin{array}{l}\text { Pursuit of both societal and strategic goals } \\
\text { Accountants search for the greater and the wider good. }\end{array}$ \\
\hline \multirow[t]{2}{*}{$\begin{array}{l}\text { An excessive } \\
\text { focus on technical } \\
\text { neutrality }\end{array}$} & \multirow[t]{2}{*}{$\begin{array}{l}\text { A higher } \\
\text { awareness of } \\
\text { the importance } \\
\text { of considering } \\
\text { morality }\end{array}$} & \multirow[t]{2}{*}{$\begin{array}{l}\text { How can I pursue the } \\
\text { human development of } \\
\text { individuals? }\end{array}$} & $\begin{array}{l}\text { Teleological } \\
\text { hierarchy principle }\end{array}$ & $\begin{array}{l}\text { Contribution to the ethical development of individuals } \\
\text { The economic dimension is a necessary instrument for } \\
\text { human development. Debates on the economic } \\
\text { performance of firms, while necessary, do not } \\
\text { supplant the central question of how accountants can } \\
\text { contribute to human development and, in particular, to } \\
\text { the ethical development of accounting professionals. }\end{array}$ \\
\hline & & & $\begin{array}{l}\text { Principle of long- } \\
\text { term commitment }\end{array}$ & $\begin{array}{l}\text { Priority to long-term commitments } \\
\text { Accountants are committed to long-term objectives } \\
\text { and not obsessed with immediate economic results. }\end{array}$ \\
\hline \multirow[t]{2}{*}{$\begin{array}{l}\text { An excessive } \\
\text { focus on technical } \\
\text { abstraction }\end{array}$} & \multirow[t]{2}{*}{$\begin{array}{l}\text { A higher } \\
\text { awareness of } \\
\text { the reality of } \\
\text { work }\end{array}$} & \multirow[t]{2}{*}{$\begin{array}{l}\text { How can I pursue the } \\
\text { personal good of each } \\
\text { member of the } \\
\text { community? }\end{array}$} & Reality principle & $\begin{array}{l}\text { Consideration of the complex reality of work } \\
\text { Accountants give priority to the complex reality of } \\
\text { work rather than profit or image by taking into } \\
\text { account the objective, subjective and social } \\
\text { dimensions of work. }\end{array}$ \\
\hline & & & Unity principle & $\begin{array}{l}\text { Consideration of work-related conflicts } \\
\text { Accountants tackle work-related conflicts and } \\
\text { dilemmas in order to overcome them. }\end{array}$ \\
\hline
\end{tabular}




\section{Discussion: towards a more ethical accounting profession}

This article builds both on existing critical studies of the accounting profession and on more positive studies regarding the role of the common good principle in business. It argues that the common good from the Catholic social tradition can help accounting professionals avoid an excessive focus on the neo-institutional features of technical accuracy, technical neutrality and technical abstraction by providing an ethical protocol that leads them to question the different community levels involved, the different orientations pursued, and the concrete difficulties of their work. This ethical protocol consists in accountants asking themselves the three questions highlighted in Section 4 (Which higher community good am I pursuing through my work as an accounting professional? Which economic, social, moral and environmental orientations am I contributing to? How do my work assignments contribute to the personal good of other members of the community?). These questions should enable accountants, auditors, controllers and other accounting professionals to envisage simultaneously a wider community good, greater human development and how to satisfy the personal good of each member. To do so, accounting professionals cannot draw solely on specific ethical codes but may benefit more from a broader set of principles providing simple, intangible and transcendental orientations that can be mobilised to find relevant moral answers in specific contexts. Unlike technical and disembodied standards and processes, the common good principles (subsidiarity, totality, teleological hierarchy, long-term commitment, reality and unity) can lead accountants to adopt a symbolic reading of the rules and to have more autonomy to make sound economic, legal and ethical decisions. Ethical principles are a way of liberating accounting professionals from a highly normative and unified representation of what ethics should be while providing them with clear orientations for guiding improved ethical actions in the public interest.

This analysis also enhances deeper reflection on ethical decision-making which has been theorised to consist of four stages: identification of an ethical dilemma, ethical judgement, ethical intentions, and ethical actions (Rest, 1986). More specifically, it may encourage accounting professionals to personalise their accounting practices by following an ethical protocol, which enables them to take the second sequential step, which is the exercise of ethical judgement. Indeed, this ethical protocol is not limited to considering public interest and evaluating the outcomes that ought to occur in a given situation, but opens the way for new 
questioning on community levels involved, on pursued human development, and on the resulting potential personal goods (see Figure 1).

Figure 1: Protocol for a re-contextualisation of accounting practices based on the common good principle

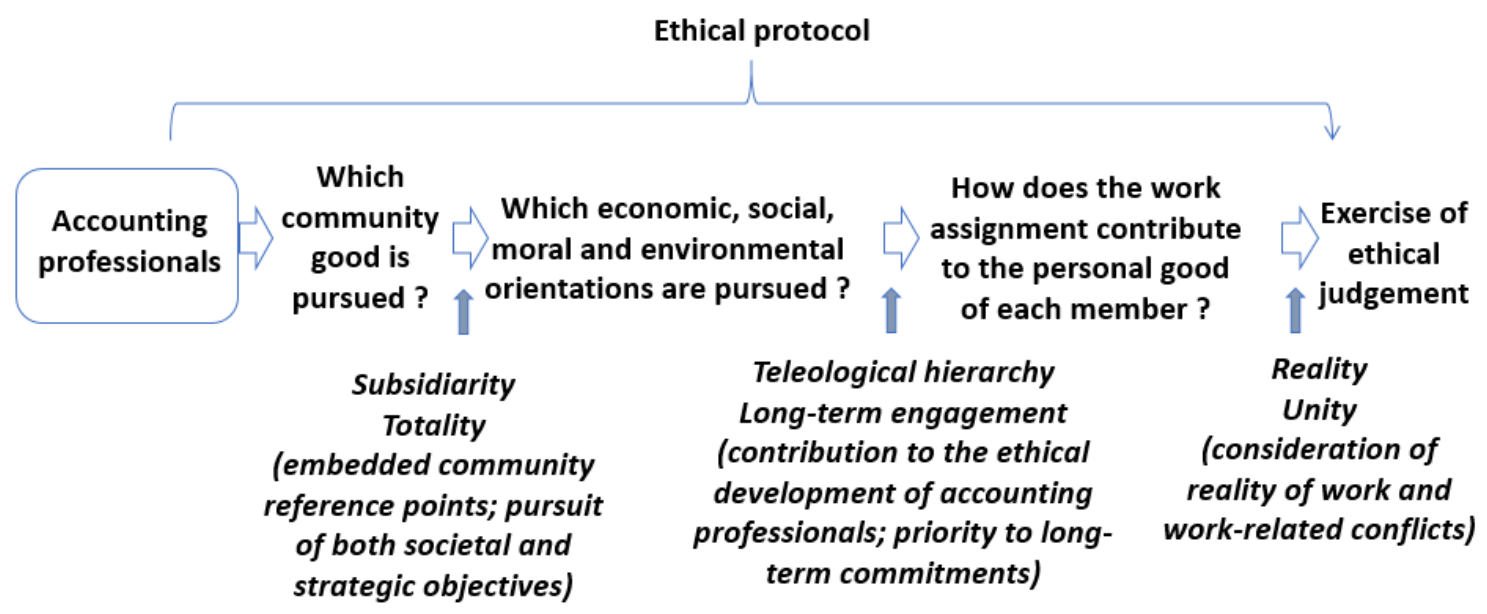

The protocol therefore promotes a systematic yet personal use of six specific ethical principles: subsidiarity, totality, teleological hierarchy, long-term commitment, reality and unity. These specific ethical principles then provide the following practical orientations that can guide the practices of accounting professionals: choice of embedded community reference points; pursuit of both societal and strategic objectives; contribution to the ethical development of accounting professionals regardless of the economic constraints; priority to long-term commitments; consideration of the complex reality of work; and consideration of work-related dilemmas. The re-contextualisation of accounting practices based on this protocol grounded on the common good principle should further contribute to associate accounting work with the pursuit of community goods, human development and the personal good of each member, as illustrated hereafter.

The principles of subsidiarity and totality refer to the definition of the community good pursued. The subsidiarity principle implies a choice of the embedded community reference points. This principle promotes accountants' involvement with and for others. Taking care of other people's needs and interests requires a capacity to be sensitive to local cultures and values. This calls for spaces where to discuss accounting purposes and consequences with those concerned. While acknowledging the promises offered by involving society (Puxty, 1991) and establishing sites of politico-ethical struggle supportive of a public-sphere for different perspectives to be voiced (Irvine \& Moerman, 2017; Lehman 2005, 2010), openness of 
communication is not unproblematic as exchanges are always distorted (Puxty, 1986). Accounting is necessarily both an instrument of emancipation and of domination (Gallhofer \& Haslam 2017; Power and Laughlin, 1996). Distinguishing between accounting practices as 'distorting' or 'enabling' can never be made absolutely (Power \& Laughlin, 1996) and this ambiguity is intrinsic to the practice (March, 1987). In this context, accountants have a primary responsibility in ensuring their work is supporting societal good and not merely particular interests. The totality principle places on accountants the requirement to combine societal and strategic goals. To aid them in this task, accounting professionals must be seen as 'learners' (Bebbington et al., 2007) and the protocol questions can prove instrumental in supporting them in their search for the greater and wider good. This search is never ending and the totality principle in particular contributes to a process-based vehicle of inquiry about the ethical goals to be pursued. The task is not an easy one since accountants are typically considered as "inhabiting a world of which the moral framework is comfortingly rigid” (in Managers and Magic by Graham Cleverley (1973) quoted in Mitchell et al., 1991). The principles are provided here for accountants to abandon the security and comfort of following 'scientific' rules and to meet the challenge of discovering what is worth pursuing for themselves and others.

Teleological hierarchy and long-term commitment principles address the human development of individuals. The teleological hierarchy principle accommodates the economic dimension with the ethical development of accounting professionals. The protocol's aim is not to override the existing attention to economic objectives but to articulate the economic dimension with other societal and social dimensions. Accounting professionals must feel empowered and better equipped to address the unavoidable tension between the prescriptions from their trade and exerting ethical judgement about its objectives and consequences allowing them to depart from extant professional codes and rules for the sake of morality. The simultaneous attention to multiple objectives and interests thus turns accountants into 'motivationally-complex decision-maker' (Miller \& O’Leary, 1987). Nonetheless, a major challenge with injecting morality in the ways in which accountants should conduct themselves is the risk to replace the hegemonic power of economic rationality with another power sharing many of the same limitations. Freedom is therefore not a guarantee of morality but it is a necessary condition for accountants to become more than mere technocrats. The long-term commitment principle is a reaffirmation of the danger associated with an obsession for short term objectives. Accounting is about creating visibility and transparency (Miller \& O’Leary, 1987; Gallhofer et al., 2015) with the associated risk that individuals then concentrate only on what is made transparent extending the market logics (Roberts, 2018). That excessive 
(sometimes exclusive) attention to simple short-term financial objectives is well documented (e.g. Lambert \& Sponem, 2005; Macintosh, 1995). In this respect, the protocol we advocate is not reducing but rather increasing complexity by providing an alternative set of rationales and a vocabulary that are not solely concerned with economics (Messner, 2009; Murphy \& O’Connell, 2017), and which may therefore mitigate the dominance of homo economicus.

The principles of reality and unity are concerned with the pursuit of the personal good of each member of the community. The reality principle acknowledges the complex reality of work beyond images and abstractions populating accounting documents, notably by taking into account the subjective and social dimensions of accounting work. In order to offer potential guidance to professional individuals engaged in the accountancy field, it is important to help them think not merely as experts but also as sentient individuals (Puyou \& Fay, 2015). One way to mobilise subjectivity is to build on situations of tensions that can prove to be morally productive (Bourguignon, 2007). Indeed, the unity principle consists in embracing situations of work-related conflicts and dilemmas, not shying away from tensions. The protocol therefore encourages accounting professionals to stand in-between conflicting values, creating tensions and difficult decisions about priorities. We acknowledge this is not a comfortable position to find oneself since it challenges the certainty to be right usually associated with the knowledge of accounting techniques (Mitchell et al., 1991). Yet the accountants' unease is necessary for wisdom to emerge from the exploration of a middle ground between rational and reasonable choices (Busco \& Quattrone, 2018). It is the careful consideration of tensions, for example between professional and commercial logic of actions, which allows for some balanced decisions to be obtained (Gendron, 2002).

The adherence to this ethical protocol can reflect and even foster a development of virtues the possession of which, according to MacIntyre (1984, p. 149), can enable an individual to achieve eudaimonia, namely blessedness, happiness and prosperity. This ethical protocol could be particularly associated with the five virtues mentioned by Francis (1990) as unique to the practice of accounting: honesty; concern for the economic status of others; sensitivity to the values of co-operation and conflict; the communicative character of accounting; and dissemination of economic information. Similarly, the three obstacles to the realisation of the virtues that Francis (1990) also suggested - the dominance of external rewards, the corrupting power of institutions, and the failure to distinguish between virtues and laws - might prevent or hinder the application of this ethical protocol. 


\section{Conclusion}

As the various technical and economic rationalities of modern organisations appear manifestly dominant in many societies (Beck, 1992; Lehman, 2005), questions have increasingly emerged with regard to the impact of such developments on human well-being and what society holds in common. This makes the common good principle an important subject for reflection and contemplation in how accountants can reclaim their profession in the service of the public interest. Drawing on the Aristotelian-Thomistic (A-T) tradition in Catholic social thought, our argument has highlighted the relevance of virtue among human agents such as accounting professionals via an ethical protocol. New structures and institutions alone cannot solve the societal problems created by various instrumental and other forces that precipitate the seemingly ubiquitous processes of standardisation and scientification. Habermas (2008) and Habermas and Ratzinger (2006) see the value of juxtaposing both science and religion in their analyses of society. Accepting this reasoning enables us to present an alternative theoretical pathway through the Catholic intellectual tradition to show how accounting professionals can pursue a clearer societal objective via the promotion of public interest.

In response to previous literature that has denounced the dominance of positivism in accounting research (e.g. Malsch \& Guérin-Paranici, 2013), the common good principle provides an optimistic and far-reaching vision. Specifically, it is embedded in an interdisciplinary framework, bridging different organisational levels, different fields - economic, legal and moral - and traversing both theory and practice. At the same time, it seeks to engage in intellectual pluralism through a particular conception of the common good as it pertains to accounting's role in improving human society. Somewhat ironically, one possible critique of the normative orientation (religious perspective) we have adopted is that it proposes a particular construction of the common good, thereby limiting the possibility of a plurality of other views and meanings. Indeed, moral values are often contested in reality. In a world where transcendental principles such as the common good are at the very least under serious threat by immanent laws as sources of legitimation and order, then it could seem a forlorn exercise. Perhaps one cannot expect a firm or a professional association to have a conscience since they lack soul and body (see epigraph in Puxty, 1991). However, the dichotomy between nature and society, fact and value (or science and religion) is often exaggerated and so is the one between techniques and symbols (Meyer \& Rowan, 1977; Power \& Laughlin, 1996). As the opening quotation by Francois Rabelais attests, science, conscience and soul must not be separated and 
it is in the individual accountant (not in science or accounting) that their articulation can be achieved. Hence, it was our ambition to equip accountants with an ethical protocol that enables them to go beyond being neutral technocrats. In this context, accounting sets open-ended procedures that are "ritually (almost liturgically) experienced” (Busco \& Quattrone, 2018, p. 2) but which are not imposing substantive truths or world visions. Our protocol is thus an attempt at legitimating, among a population of accounting professionals, the importance of subjective moral judgment for emancipation to 'win over' domination and marginalisation.

Latour (2004) concurs and argues that science, nature, values and politics are inherent in all collective entities. Interestingly, Latour's account of the role of professionals in the future of our societies, and notably the duty to identify what is expendable and what is essential to a successful political ecology, does not mention the contribution of accountants alongside the ones from moralists, scientists, politicians, diplomats and economists. In Latour's (2004) vision of society, accounting may have become already a sub-discipline of neo-classical economics (Ravenscroft \& Williams, 2009) offering no possibility to contribute to the judgement of the ethical and practical propriety of behaviours. Our endeavour is therefore a modest but political attempt to reposition accounting away from Science (with a capital S) but among the sciences (to adopt a distinction made by Latour, 2004) able to contribute to the future of democratic societies.

Previous literature has determined that managers can be divided between the model of a rational definition of objectives centred on productivity and efficiency, and the model of human relationships focused on the development of human resources and internal harmony (Abela, 2001; Quinn \& Rohrbaugh, 1981). Future research based on this article could envisage a clearer articulation between accounting processes that are necessarily standardised, and the need to acknowledge the latitude to undertake actual accounting practices that are ethical. Professional accountants may aspire to principles and yet it is the rules such as "compliance with technical and quality standards” that they must follow (Preston et al., 1995, p. 527). Law, like prescriptions and standards, even ethical ones, pronounce actions and agents to be right, wrong, good and bad based on rules and regulations rather than on the effect they have on the feelings and interests of other persons or sentient beings (Velayutham, 2003). A second area for future work could involve exploring how managerial authority can encourage this shift in the perception of ethical norms and of the wider purposes of the accounting profession. Such lines of research could help us better understand how to ensure that management is open to these ethical orientations in a context that is particularly focused on the financial and technical aspects of business operations. 
The public interest has planted the seeds of an awareness of the common good. The common good principle goes beyond analysing the consequences of our own actions for society and presents three main advantages: first, it integrates consideration of the different levels of community good, including the community good of society, connecting them by subsidiarity and totality; second, it integrates all the fields - ethical, social and economic - connecting them by a teleological hierarchy and long-term engagement; and third, it focuses on the complex reality of work and assignments, connecting theory and practice. The main contribution of this article has been to develop an ethical protocol based on the notion of common good to help accounting professionals avoid the excessive objectification of their practices. The protocol does so by raising questions about ethics, not by setting ethical standards or listing best practices, but by promoting principles such as subsidiarity, totality, teleological hierarchy, longterm commitment, reality and unity to guide practitioners in their desire for ethical actions. This, we contend, will enhance the public interest contribution of accounting professionals and their work.

\section{References}

Abbott, A. (1988). The system of professions. An essay on the division of expert labour. Chicago: The University of Chicago Press.

Abela, A. (2001). Profit and more: Catholic social teaching and the purpose of the firm. Journal of Business Ethics, 31(2), 107-116.

Acevedo, A. (2012). Personalist business ethics and humanistic management: Insights from Jacques Maritain. Journal of Business Ethics, 105(2), 197-219.

Addison, S., \& Mueller, F. (2015). The dark side of professions: the big four and tax avoidance. Accounting, Auditing and Accountability Journal, 28(8), 1263-1290.

Aho, J. (1985). Rhetoric and the invention of double entry bookeeping. Rhetorica, 3(1), 21-43.

Aho, J. (2005). Confession and bookkeeping. The religious, moral and rhetorical roots of modern accounting. Albany: State University of New York.

Alford, H., \& Naughton, M. (2002). Beyond the shareholder model of the firm: Working toward the common good of a business. In S. Cortright \& M. Naughton (Eds.), Rethinking the purpose of business: Interdisciplinary essays from the Catholic social tradition (pp. 27-47). Notre Dame: University of Notre Dame Press.

Argandona, A. (1998). The stakeholder theory and the common good. Journal of Business Ethics, 17(9/10), 1093-1102.

Arjoon, S., Turriago-Hoyos, A., \& Thoene, U. (2018). Virtuousness and the common good as a conceptual framework for harmonizing the goals of the individual, organizations, and the economy. Journal of Business Ethics, 147(1), 143-163. 
Baker, C. (2014). Alternative perspectives on accounting in the public interest. In S. Mintz (Ed.), Accounting for the public interest: Perspectives on accountability, professionalism and role in society. New York: Springer.

Ball, A., \& Osborne, S. (2011). Introduction: Accounting-for the common good? In A. Ball \& S. Osborne (Eds.), Social accounting and public management: Accountability for the common good (pp. 1-7). New York: Routledge.

Bebbington, J., Brown, J., Frame, B., \& Thomson, I. (2007). Theorizing engagement: The potential of a critical dialogic approach. Accounting, Auditing and Accountability Journal, 20(3), 356-381.

Beck, U. (1992). Risk society: Towards a new modernity. London: Sage.

Benedict XVI (2009) Caritas in veritate. Encyclical letter [retrieved from http://w2.vatican.va/content/benedict-xvi/en/encyclicals/documents/hf_benxvi_enc_20090629_caritas-in-veritate.html]

Bourguignon, A. (2007). Are management systems ethical? The reification perspective. In M.-L. Djelic \& R. Vranceanu (Eds.), Moral foundations of management knowledge. Cheltenham: Edward Elgar.

Boyce, G. (2014). Professionalism, the public interest, and social accounting. In S. Mintz (Ed.), Accounting for the public interest: Perspectives on accountability, professionalism and role in society. New York: Springer.

Broadbent, J., \& Laughlin, R. (2003). Control and legitimation in government accountability processes: The private finance initiative in the UK. Critical Perspectives on Accounting, 14(1/2), 23-48.

Busco, C., \& Quattrone, P. (2018). Performing business and social innovation through accounting inscriptions: An introduction. Accounting, Organizations and Society, in press. [https://doi.org/10.1016/j.aos.2018.03.002]

Carcello, J. (2009). Governance and the common good. Journal of Business Ethics, 89(supplement 1), 11-18.

Chandler, R. (2016). Questions of ethics and etiquette in the Society of Accountants in Edinburgh, 1853-1951. Accounting History, 22(2), 179-192.

Cleverley, G. (1973). Managers and magic. New York: Pelican.

Cochran, C. (1974). Political science and 'the public interest'. The Journal of Politics, 36(2), 327-355.

Cooper, D., \& Robson, K. (2006). Accounting, professions and regulation: Locating the sites of professionalization. Accounting, Organizations and Society, 31(4-5), 415-444.

Cornwall, J., \& Naughton, M. (2003). Who is the good entrepreneur? An exploration within the Catholic social tradition. Journal of Business Ethics, 44(1), 61-75.

Cortright, S., \& Naughton, M. (Eds.). (2002). Rethinking the purpose of business: Interdisciplinary essays from the Catholic social tradition. Notre Dame: University of Notre Dame Press.

Costa, E., \& Ramus, T. (2012). The Italian Economia Aziendale and Catholic social teaching: How to apply the common good principle at the managerial level. Journal of Business Ethics, 106(1), 103-116. 
De Bettignies, H.-C., \& Lepineux, F. (2009). Can multinational corporations afford to ignore the global common good? Business and Society Review, 114(2), 153-182.

Deegan, C. (2017). Twenty five years of social and environmental accounting research within Critical Perspectives on Accounting: Hits, misses and ways forward. Critical Perspectives on Accounting, 43, 65-87.

Deissenberg, C, \& Alvarez, G. (2002). Cheating for the common good in a macroeconomic policy game. Journal of Economic Dynamics and Control, 26(9/10), 1457-1479.

Dellaportas, S., \& Davenport, L. (2008). Reflections on the public interest in accounting. Critical Perspectives on Accounting, 19(7), 1080-1098.

Diggs, B. (1973). The common good as reason for political action. Ethics, 83(4), 283-293.

Everett, J., \& Tremblay, M.-S. (2014). Ethics and internal audit: Moral will and moral skill in a heteronomous field. Critical Perspectives on Accounting, 25(3), 181-196.

Faure, B., \& Rouleau, L. (2011). The strategic competence of accountants and middle managers in budget making. Accounting, Organizations and Society, 36(3), 167-182.

Ferguson, J., Collison, D., Power, D., \& Stevenson, L. (2009). Constructing meaning in the service of power: An analysis of the typical modes of ideology in accounting textbooks. Critical Perspectives on Accounting, 20(8), 896-909.

Finnis, J. (1986). Natural law and natural rights. Oxford: Clarendon.

Francis, J. (1990). After virtue? Accounting as a moral and discursive practice. Accounting, Auditing and Accountability Journal, 3(3), 5-17.

Francis (2013) Evangelii gaudium. Apostolic exhortation [retrieved from https://w2.vatican.va/content/francesco/en/apost_exhortations/documents/papafrancesco_esortazione-ap_20131124_evangelii-gaudium.html]

Gallhofer, S., \& Haslam, J. (2017). Some reflections on the construct of emancipatory accounting: Shifting meaning and the possibilities of a new pragmatism. Critical Perspectives on Accounting, in press.[https://doi.org/10.1016/j.cpa.2017.01.004]

Gallhofer, S., Haslam, J., \& Yonekura, A. (2015). Accounting as differentiated universal for emancipatory praxis: Accounting delineation and mobilisation for emancipation(s) recognising democracy and difference. Accounting, Auditing and Accountability Journal, 28(5), 846-874.

Gendron, Y. (2002). On the role of the organization in auditors' client-acceptance decisions. Accounting, Organizations and Society, 27(7), 659-684.

Gill, M. (2011). Accountants' truth: Knowledge and ethics in the financial world. Oxford: Oxford University Press.

Goody, J. (1977). The domestication of the savage mind. Cambridge: Cambridge University Press.

Goretzki, L., Strauss, E., \& Weber, J. (2013). An institutional perspective on the changes in management accountants' professional role. Management Accounting Research, 24(1), 41-63.

Gowthorpe, C., \& Amat, O. (2005). Creative accounting: Some ethical issues of macro- and micro-manipulation. Journal of Business Ethics, 57(1), 55-64.

Grafton, A., \& Jardine, L. (1986). From humanism to the humanities: Education and the liberal arts in fifteenth and sixteenth-century Europe. London: Duckworth. 
Habermas ([1981] 1987). Theory of communicative action. Trans. by T. McCarthy. Boston: Beacon Press.

Habermas, J. (2008). Between naturalism and religion: Philosophical essays. Cambridge: Polity Press.

Habermas, J., \& Ratzinger, J. (2006). The dialectics of secularization: On reason and religion. San Francisco: Ignatius Press.

Hanlon, G. (1996). 'Casino capitalism' and the rise of the 'commercialised' service class - an examination of the accountant. Critical Perspectives on Accounting, 7(3), 339-363.

Hartmann, F., \& Maas, V. (2010). Why business unit controllers create budget slack: Involvement in management, social pressure, and Machiavellianism. Behavioral Research in Accounting, 22(2), 27-49.

Horton, K., \& de Araujo Wanderlay, C. (2018). Identity conflict and the paradox of embedded agency in the management accounting profession: Adding a new piece to the theoretical jigsaw. Management Accounting Research, 38, 39-50.

Hoskin, K., \& Macve, R. (1986). Accounting and the examination: a genealogy of disciplinary power. Accounting, Organizations and Society, 11(2), 105-136.

Irvine, H., \& Moerman, L. (2017). Gambling with the public sphere: Accounting's contribution to debate on social issues. Critical Perspectives on Accounting, 48(1), 35-52.

Jarvenpaa, M. (2007). Making business partners: A case study on how management accounting culture was changed. European Accounting Review, 16(1), 99-142.

Lail, B., MacGregor, J., Marcum, J., \& Stuebs, M. (2017). Virtuous professionalism in accountants to avoid fraud and to restore financial reporting. Journal of Business Ethics, 140(4), 687-704.

Lambert, C., \& Sponem, S. (2005). Corporate governance and profit manipulation: A French field study. Critical Perspectives on Accounting, 16(6), 717-748.

Latour, B. (2004). Politics of nature: How to bring the sciences into democracy. Cambridge, MA: Harvard University Press.

Lee, T. (1995). The professionalization of accountancy. A history of protecting the public interest in a self-interested way. Accounting, Auditing and Accountability Journal, 8(4), 48-69.

Lehman, G. (2005). A critical perspective on the harmonisation of accounting in a globalising world. Critical Perspectives on Accounting, 16(7), 975-992.

Lehman, G. (2010). Perspectives on accounting, commonalities and the public sphere. Critical Perspectives on Accounting, 21(8), 724-738.

Lehman, G. (2014). Moral will, accounting and the phronemos. Critical Perspectives on Accounting, 25(3), 210-216.

Maas, V., \& Matejka, M. (2009). Balancing the dual responsibilities of business unit controllers: Field and survey evidence. The Accounting Review, 84, 1233-1253.

Machiavelli, N. ([1531] 1996). Discourses on Livy. Trans. by H. Mansfield and N. Tarcov. Chicago: University of Chicago Press.

MacIntyre, A. (1984). After Virtue, Notre Dame: University of Notre Dame Press.

Macintosh, N. (1995). The ethics of profit manipulations: A dialectic of control analysis. Critical Perspectives on Accounting, 6(4), 289-315. 
Malsch, B., \& Guénin-Paracini, H. (2013). The moral potential of individualism and instrumental reason in accounting research. Critical Perspectives on Accounting, 24(1), 74-82. March, J. G. (1987). Ambiguity and accounting: The elusive link between information and decision making. Accounting, Organizations and Society, 12(2), 153-168.

Maritain, J. (1947). The person and the common good. Notre Dame: University of Notre Dame Press.

Martin, F. (2011). Human development and the pursuit of the common good: Social psychology or Aristotelian virtue ethics? Journal of Business Ethics, 100(supplement 1), 89-98.

McCarthy, T. (1994). Kantian constructivism and reconstructivism: Rawls and Habermas in dialogue. Ethics, 105(1), 44-63.

McMillan, K. (2010). The institute of accounts: A community of the competent. Accounting, Business and Financial History, 9(1), 7-28.

Melé, D. (2005). Exploring the principle of subsidiarity in organisational forms. Journal of Business Ethics, 60(3), 293-305.

Melé, D. (2009). Integrating personalism into virtue-based business ethics: The personalist and the common good principles. Journal of Business Ethics, 88(1), 227-244.

Melé, D. (2012). The firm as a community of persons: A pillar of humanistic business ethos. Journal of Business Ethics, 106(1), 89-101.

Messner, J. (1965). Social ethics: Natural law in the modern world. Saint Louis: Herder.

Messner, M. (2009). The limits of accountability. Accounting, Organizations and Society, 34(8), 918-938.

Meyer, J. (1986). Social environments and organizational accounting. Accounting, Organizations and Society, 11(4/5), 345-356.

Meyer, J., \& Jepperson, R. (2000). The 'actors' of modern society: The cultural construction of social agency. Sociological Theory, 18(1), 100-120.

Meyer, J., \& Rowan, B. (1977). Institionalized organizations: Formal structure as myth and ceremony. American Journal of Sociology, 83(2), 340-363.

Miller, P., \& O'Leary, T. (1987). Accounting and the construction of the governable person. Accounting, Organizations and Society, 12(3), 235-265.

Miller, P., \& O’Leary, T. (1994). Accounting, ‘economic citizenship’ and the spatial reordering of manufacture. Accounting, Organizations and Society, 19(1), 15-43.

Mitchell, A., Puxty, A., Sikka, P., \& Willmott, H. (1991). Accounting for change: Proposals for reform of audit and accounting. London: Fabian Society.

Mounier, E. (1970). Personalism. Trans by P. Mairet. Notre Dame: University of Notre Dame Press.

Murphy, T., \& O'Connell, V. (2017). Challenging the dominance of formalism in accounting education: an analysis of the potential of stewardship in light of the evolution of legal education. Critical Perspectives on Accounting, 44(1), 1-29.

Nelson, J. (1993). Account and acknowledge, or represent and control? On post-modern politics and economics of collective responsibility. Accounting, Organizations and Society, 18(2/3), 207-229. 
Neu, D. (2000). 'Presents' for the 'Indians': Land, colonialism and accounting in Canada. Accounting, Organizations and Society, 25(2), 163-184.

O’Brien, T. (2009). Reconsidering the common good in a business context. Journal of Business Ethics, 85(supplement 1), 25-37.

O’Regan, P. (2008). 'Elevating the profession': The Institute of Chartered Accountants in Ireland and the implementation of social closure strategies 1888-1909. Accounting, Business and Financial History, 18(1), 35-59.

O’Regan, P., \& Killian, S. (2014). 'Professionals who understand': Expertise, public interest and societal risk governance. Accounting, Organizations and Society, 39(8), 615-631.

Pallot, J. (1991). The legitimate concern with fairness: A comment. Accounting, Organizations and Society, 16(2), 201-208.

Pontifical Commission of Justice and Peace. (2004). Compendium of the social doctrine of the church. Vatican City: Libreria Editrice.

Power, M. (1997). The audit society. Rituals of verification. Oxford: Oxford University Press.

Power, M., \& Laughlin, R. (1996). Habermas, law and accounting. Accounting, Organizations and Society, 21(5), 441-465.

Preston, A., Cooper, D., Scarbrough, P., \& Chilton, R. (1995). Changes in the code of ethics of the U.S. accounting profession, 1917 and 1988: The continual quest for legitimation. Accounting, Organizations and Society, 20(6), 507-546.

Puxty, A. (1986). Social accounting as immanent legitimation: A critique of a technicist ideology. Advances in Public Interest Accounting, 1, 95-111.

Puxty, A. (1991). Social accountability and universal pragmatics. Advances in Public Interest Accounting, 4, 35-45.

Puyou, F.-R., \& Faÿ, E. (2015). Cogs in the wheel or spanners in the works? A phenomenological approach to the difficulty and meaning of ethical work for financial controllers. Journal of Business Ethics, 128(4), 863-876.

Quattrone, P. (2015). Governing social orders, unfolding rationality, and Jesuit accounting practices: A procedural approach to institutional logics. Administrative Science Quarterly, 60(3), 411-445.

Quinn, R., \& Rohrbaugh, J. (1981). A competing values approach to organizational effectiveness. Public Productivity Review, 5(2), 122-140.

Rasmussen, D. (1990). Reading Habermas. Oxford: Blackwell.

Ravenscroft, S., \& Denison, C. (2014). Social and economic implications of increasing income inequality: Accountability concerns. In S. Mintz (Ed.), Accounting for the public interest: Perspectives on accountability, professionalism and role in society. New York: Springer.

Ravenscroft, S., \& Williams, P. (2009). Making imaginary worlds real: The case of expensing employee stock options. Accounting, Organizations and Society, 34(6-7), 770-786.

Rest, J. (1986). Moral development: Advances in research and theory. New York: Praeger.

Richardson, A. (1987). Accounting as legitimating institution. Accounting, Organizations and Society, 12(4), 341-355.

Richardson, A., \& Eberlein, B. (2011). Legitimating transnational standard-setting: The case of the International Accounting Standards Board. Journal of Business Ethics, 98(2), 217-245. 
Roberts, J. (2018). Managing only with transparency: The strategic functions of ignorance. Critical Perspectives on Accounting, in press. [https://doi.org/10.1016/j.cpa.2017.12.004]

Rogers, R., Dillard, J., \& Yuthas, K. (2005) The accounting profession: Substantive change and/or image management. Journal of Business Ethics, 58(1), 159-176.

Schlag, M. (2012). The encyclical Caritas in Veritate, Christian tradition and the modern world. In M. Schlag \& J. Mercado (Eds.), Free markets and the culture of the common good (pp. 93109). Dordrecht: Springer.

Sikka, P., \& Willmott, H. (1995). The power of 'independence': Defending and extending the jurisdiction of accounting in the United Kingdom. Accounting, Organizations and Society, 20(6), 547-581.

Simm, K. (2011). The concept of common good and public interest: From Plato to biobanking. Cambridge Quarterly of Healthcare Ethics, 20(4), 554-562.

Sison, A., \& Fontrodona, J. (2011). The common good of business: Addressing a challenge posed by Caritas in Veritate. Journal of Business Ethics, 100 (supplement 1), 99-107.

Sison, A., \& Fontrodona, J. (2012). The common good of the firm in the Aristotelian-Thomistic tradition. Business Ethics Quarterly, 22(2), 211-246.

Sison, A., \& Fontrodona, J. (2013). Participating in the common good of the firm. Journal of Business Ethics, 113(4), 611-625.

Sison, A. J., Ferrero, I., \& Guitian, G. (2016). Human dignity and the dignity of work: Insights from Catholic social teaching. Business Ethics Quarterly, 26(4), 503-528.

Smith, T. (1999). Aristotle on the conditions for and limits of the common good. American Political Science Review, 93(3), 625-636.

Spitzeck, H. (2011). An integrated model of humanistic management. Journal of Business Ethics, 99(1), 51-62.

Townley, B., Cooper, D., \& Oakes, L. (2003). Performance measures and the rationalization of organizations. Organization Studies, 24(7), 1045-1071.

Velayutham, S. (2003). The accounting profession's code of ethics: Is it a code of ethics or a code of quality assurance. Critical Perspectives on Accounting, 14(4), 483-503.

Williams, P. (2004). You reap what you sow: The ethical discourse of professional accounting. Critical Perspectives on Accounting, 15(6/7), 995-1001.

Williams, P. (2014). The IFAC framework: International accounting and the public interest. In S. Mintz (Ed.), Accounting for the public interest: Perspectives on accountability, professionalism and role in society. New York: Springer.

Young, J., \& Williams, P. (2010). Sorting and comparing: Standard-setting and 'ethical' categories. Critical Perspectives on Accounting, 21(6), 509-521. 